\title{
Multi-Criteria Analysis for Business Location Decisions
}

\author{
Virginia Perez-Benitez ${ }^{1, *(\mathbb{D})}$, German Gemar ${ }^{2, *(\mathbb{D})}$ and Mónica Hernández ${ }^{3, *(D)}$ \\ 1 PhD Program in Economics and Business, Campus El Ejido, Universidad de Málaga, 29071 Málaga, Spain \\ 2 Department of Economics and Business Administration, Campus El Ejido, Universidad de Málaga, \\ 29071 Málaga, Spain \\ 3 Department of Applied Economics (Mathematics), Campus El Ejido, Universidad de Málaga, \\ 29071 Málaga, Spain \\ * Correspondence: virginiaperez@uma.es (V.P.-B.); ggemar@uma.es (G.G.); m_huelin@uma.es (M.H.)
}

check for updates

Citation: Perez-Benitez, V.; Gemar, G.; Hernández, M. Multi-Criteria Analysis for Business Location Decisions. Mathematics 2021, 9, 2615. https://doi.org/10.3390/math 9202615

Academic Editor: Vicente Coll-Serrano

Received: 9 September 2021 Accepted: 10 October 2021 Published: 17 October 2021

Publisher's Note: MDPI stays neutral with regard to jurisdictional claims in published maps and institutional affiliations.

Copyright: (c) 2021 by the authors. Licensee MDPI, Basel, Switzerland. This article is an open access article distributed under the terms and conditions of the Creative Commons Attribution (CC BY) license (https:// creativecommons.org/licenses/by/ $4.0 /)$.

\begin{abstract}
Choosing the physical place in which to locate a company or make investments is a strategic decision that managers must make when their business activities begin and as they expand. These decisions are key to firms' survival. This study sought to shed light on this decision problem and assist managers in making these decisions. The first research objective was to examine the different dimensions that decision makers should consider regarding locations. The second objective was to test the efficacy of multi-criteria analysis methods regarding this decision problem. More specifically, this study applied a combination of the preference ranking organization method for enrichment of evaluations and the geometric analysis for interactive aid method, complemented by the analytical hierarchy process. The last objective was to rank major European cities on their suitability as business locations. The results include a preferential ranking of 66 European cities. London is the best positioned in all dimensions, followed by Paris and Barcelona. The findings' originality comes from the inclusion of dimensions such as climate, security, and technology, which are given little weight in other similar indices, as well as the fresh approach to this decision problem from a business perspective and the combination of methodologies.
\end{abstract}

Keywords: business location; multi-criteria decision analysis; preference ranking organization method for enrichment of evaluations (PROMETHEE); analytic hierarchy process (AHP); cities; geometric analysis for interactive aid (GAIA)

\section{Introduction}

Historically, managers face the fundamental decision problem of choosing a physical place in which to locate their firm when they are first established or additional locations to which to expand during internationalization. These decisions are considered of strategic importance and fundamental to businesses' success [1]. Many factors are traditionally weighed before making location decisions, such as agglomeration economies, workforces' level of education, population density, energy costs, local economic conditions, or raw material supplies [2,3].

Currently, managers must consider additional factors that, due to their company's surrounding environment, have acquired greater importance. These decision criteria include, among others, access to technology, regional legal and political security, gender equality, climate, and environmental factors. Given these complex variables, location decisions have become even more complicated, turning them into multi-criteria decision problems.

The literature includes many indices that have compared different cities based on varied dimensions and indicators. The Mori Memorial Foundation's Global Power City Index [4] and the Instituto de Estudios Superiores de la Empresas's Cities in Motion Index [5] are especially important. At the subnational level, the relevant indices are scarcer, but a significant contribution at the European level is the European Cities Quality Index (ECQI) [6]. Most of the cited indices, however, focus on cities' quality of life, and only a few evaluate metropolises from an investment perspective. 
The present research's main objective was to help managers make decisions about the location of the company. The study focused on Europe, identifying the best business locations among 66 cities based on 11 criteria (i.e., dimensions) and creating a preferential ranking of these metropolises. To this end, the preference ranking organization method for enrichment of evaluations (PROMETHEE) [7] was selected for its simplicity and practicality compared to other multi-criteria decision models (MCDMs). This method was combined with the analytical hierarchy process (AHP) technique [8], which was used to weight the selected criteria.

The present results' main contributions arise from the inclusion of a climate dimension in the research model and the integration of the PROMETHEE and AHP to facilitate weighting the factors chosen. In addition, this study focused on dimensions of importance to management-level decisions rather than exclusively on cities' quality of life, confirming that the criteria with the greatest weight in this decision problem need to be security and the available technology.

The remainder of this paper is divided into the following sections. The second half of this introduction provides a review of the literature on aspects relevant to location decisions. The second section explains the methodology applied in the research, including details of the database used and the criteria or dimensions analyzed using different indicators. The third section presents the results, and the final sections compare the findings with similar studies and offer conclusions.

\section{Literature Review}

Business location decisions are considered to be of strategic importance as they have a significant influence on companies' survival and on their performance results [9]. The literature offers studies that have examined both variables' relationship in various business sectors, including research carried out on the Spanish hotel sector $[10,11]$. The choice of where to locate investments abroad is also a key decision within firms' internationalization strategies [12]. This decision problem has been studied at the country [13,14] and subnational level [15].

Some authors have highlighted the role of "global cities" in subnational contexts as a key factor in the internationalization of multinational companies [16]. The concept of a global city has, in general, been widely researched by academics $[17,18]$. According to Goerzen et al. [16], global cities present a strong degree of connectivity, cosmopolitan environment, and high density of services. Based on this definition, Europe can be said to be home to many global cities [19].

These metropolises' characteristics make them attractive to investors and managers who seek to implement their organizations' internationalization strategies. The specific facilities that cities offer and their agglomerations of activities and services increase the potential for interactions and knowledge transfer. Thus, global cities often become the cradle of new innovative companies that prefer to locate their facilities in places rich in specific knowledge in the early stages of their product cycle [20-23]. In addition, the patterns followed by human settlements include growing urbanization in recent centuries so that more than half of the world's population now lives in cities [23]. The latter naturally offer a multitude of business opportunities [22].

Given the above findings, most decisions about where to locate business investments ultimately concentrate on large metropolises, although there are exceptions as Bartik's research shows [24]. These decisions' intrinsic difficulty lies in choosing the best city in which to conduct business from among the multitude of urban centers available. To solve this problem, managers or decision makers must consider a multitude of criteria, which makes using mathematical multi-criteria analysis techniques quite suitable tools.

Among the MCDMs available, Brans and Vincke's PROMETHEE [7] is one of the best designed. This method facilitates preference rankings of the alternatives under evaluation, as well as being able to consider both quantitative and qualitative criteria's importance to the decision problem at hand. PROMETHEE has been shown to have many practical 
applications in different areas, such as the evaluation of tourism destinations' competitiveness [25], hotel web pages [26], and composting technologies' sustainability [27].

Geometric analysis for interactive aid (GAIA) [28] is commonly used with PROMETHEE to provide a more visual representation of results. In the PROMETHEE, each criterion's weight must be determined. Researchers have recommended the hierarchical analytical process (AHP) for this task because the combination of these methods generates operational synergies [29]. Therefore, the two supplemental methods were also applied in the present study.

\section{Materials and Methods}

This section details the different data and methods used in this research. Figure 1 presents the flow of steps carried out in the study.

\section{Database}

- Identify alternatives,criteria and

indicators and collect data from different

sources

Variable reduction by

confirmatory factor analysis

Assign weights with AHP

method

Apply the PROMETHEE method

- Step 1: Make pair-wise comparations

- Step 2: Choose the preference function

- Step 3: Get the outranking net flow

Figure 1. Flow of steps.

\subsection{Database}

The database was created with information from different reliable sources, most of which are official suppliers of statistics such as Eurostat, World Bank, World Health Organization, and Organization for Economic Co-operation and Development (OECD). The period covered is 2014 to 2020, depending on the indicator considered and always including the latest year for which data are available. Although the data were largely gathered at the city level, serious difficulties were encountered in finding disaggregated data at this level for some variables, so a portion of the data were found only at the regional or country level.

The cities, criteria, and indicators were selected with reference to other well-respected important indices specifically the Cities in Motion Index [5] and ECQI [6]. Following the latter index's example, 66 European cities were chosen, which are listed in Table 1. The database with all the indicators and sources used are detailed in Table 2.

Ten criteria and 48 indicators were initially selected for this study. A brief description of each criteria is provided below. 
Table 1. European cities.

\begin{tabular}{|c|c|c|c|c|c|c|c|c|}
\hline & Country & City & & Country & City & & Country & City \\
\hline 1 & Germany & Berlin & 23 & Estonia & Tallinn & 45 & The Netherlands & The Hague \\
\hline 2 & Germany & Cologne & 24 & Finland & Helsinki & 46 & Poland & Katowice \\
\hline 3 & Germany & Hamburg & 25 & France & Paris & 47 & Poland & Krakow \\
\hline 4 & Germany & Munich & 26 & France & Lyon & 48 & Poland & Warsaw \\
\hline 5 & Austria & Vienna & 27 & France & Marseille & 49 & Portugal & Oporto \\
\hline 6 & Belgium & Brussels & 28 & France & Lille & 50 & Portugal & Lisbon \\
\hline 7 & Belgium & Antwerp & 29 & France & Toulouse & 51 & United Kingdom & Edinburgh \\
\hline 8 & Bulgaria & Sofia & 30 & Greece & Athens & 52 & United Kingdom & Glasgow \\
\hline 9 & Bulgaria & Plovdiv & 31 & Greece & Thessaloniki & 53 & United Kingdom & Cardiff \\
\hline 10 & Cyprus & Nicosia & 32 & Hungary & Budapest & 54 & United Kingdom & London \\
\hline 11 & Denmark & Copenhagen & 33 & Ireland & Dublin & 55 & United Kingdom & Birmingham \\
\hline 12 & Denmark & Aarhus & 34 & Iceland & Reykjavik & 56 & United Kingdom & Manchester \\
\hline 13 & Slovakia & Bratislava & 35 & Italy & Milan & 57 & United Kingdom & Leeds \\
\hline 14 & Slovenia & Ljubljana & 36 & Italy & Rome & 58 & United Kingdom & Liverpool \\
\hline 15 & Spain & Madrid & 37 & Italy & Turin & 59 & United Kingdom & Belfast \\
\hline 16 & Spain & Barcelona & 38 & Italy & Naples & 60 & Croatia & Zagreb \\
\hline 17 & Spain & Valencia & 39 & Italy & Palermo & 61 & Czechia & Brno \\
\hline 18 & Spain & Sevilla & 40 & Latvia & Riga & 62 & Czechia & Prague \\
\hline 19 & Spain & Bilbao & 41 & Lithuania & Vilnius & 63 & Romania & Bucharest \\
\hline 20 & Spain & Zaragoza & 42 & Malta & Valleta & 64 & Sweden & Stockholm \\
\hline 21 & Spain & Malaga & 43 & The Netherlands & Rotterdam & 65 & Sweden & Gothenburg \\
\hline 22 & Spain & Murcia & 44 & The Netherlands & Amsterdam & 66 & Luxembourg & Luxembourg \\
\hline
\end{tabular}

\subsubsection{Health}

Cities' existing level of health is important for both residents' lives and economic development since good health provides companies with vigorous human capital and guarantees adequate conditions for the general population's improved lifestyles and prosperity [30]. Over time, regions' economic development has been closely linked with their health system's quality, so including this dimension in the research model was essential. Health was evaluated using indicators such as healthy life expectancy (HALE) at birth, level of health spending, available hospital beds, and each city's ranking according to the Healthcare Access and Quality (HAQ) index [31].

\subsubsection{Education}

Countries' educational level, as well as of their cities is also crucial for economic development, providing qualified labor and talent to local companies. Proximity to human capital has typically been a significant location factor considered in business location decisions [32]. This criterion was assessed by taking into account the percentages of the population with secondary and tertiary education. Other indicators were the surrounding country's score in the Program for International Student Assessment's (PISA) reports [33] and the number of each city's universities placing at the top of the Quacquarelli Symonds (QS) World Universities Ranking.

\subsubsection{Employment and Income}

This variable assesses cities' level of employment and working conditions, as well as the distribution of wealth, via indicators such as the unemployment rate, ease of doing business rankings [34], working day, and the relevant country's score on the Gini index. All these factors influence the residents' purchasing power and thus their levels of consumption, so this variable was particularly relevant to the research model.

\subsubsection{Environment}

The physical environment's quality is increasingly important for regions' sustainable development. Recently, more countries worldwide have committed to improving this quality ever since the planet's dangerous deterioration as a result of climate change became 
evident [35]. This variable was assessed based on air and water quality, waste generation and treatment, and renewable energy.

\subsubsection{Equality}

Achieving full gender equality is a societal challenge that all developed countries strive for, and improvements in this area are associated with higher levels of prosperity and progress. Equality can have a multiplier effect that promotes overall economic growth [36]. This factor was measured using indicators taken from indices such as the Gender Equality Index [37], Global Gender Gap Index [38], and the Gender Inequality Index [39].

\subsubsection{Leisure}

Cities' leisure and entertainment activities also influence their economic development because these features attract people, whether they are visiting tourists or workers from local companies who value these pastimes [40]. To evaluate this factor, the research model included indicators such as the number of museums, theaters, shows, and parks in each city, as well as the volume of conferences hosted that could increase these urban centers' scientific, academic, and business relevance. The latter was assessed via a European ranking prepared by the International Congress and Convention Association (ICCA) [41].

\subsubsection{Accommodations and Security}

To evaluate accommodations' availability and affordability in each city, indicators included, for example, the percentage of total income dedicated to paying mortgages, average amount of rent, and ratio between average salary and average price of accommodations. Citizen security, in turn, was measured using crime rates, as well as perceived levels of transparency and corruption in these cities [42]. This aspect is of utmost importance to companies' smooth development and perceptions of legal security, as well as the expected absence of corruption.

\subsubsection{Mobility}

Both residents and tourists or new investors must feel that the city in question has a fluid, safe transport system [43]. This variable was measured via citywide indicators such as the level of traffic congestion and number of fatal traffic accidents.

\subsubsection{Climate}

Incorporating each city's climate into the decision-support model was an innovation of great importance because of climate's impacts on residents' quality of life and cities' ability to attract visitors as tourists or workers [44]. In both cases, a greater influx of people can have a positive effect on cities' economic development and improve their position regarding potential investors. Climate was evaluated based on the climate index developed by Soler et al. [45], in which each city is scored according to the average temperature, days of rain, and volume of precipitation.

\subsubsection{Technology}

The twenty-first century has been marked by important advances in information and communication technology, so companies have had to adapt quickly to new increasingly technological business contexts [46]. Thus, this variable needed to be included in the present decision-support model. When choosing a location, managers have to consider cities' level of technology and connectivity as this will determine how well many of their firm's internal business processes will function. To assess this factor, the analyses incorporated indicators such as metropolises' broadband access and Internet speed. The research model also took into account the Global Innovation Index prepared by the World Intellectual Property Organization (WIPO) [47]. A description of all the criteria and indicators is given in Table 2. 
Table 2. Dimensions and indicators.

\begin{tabular}{|c|c|c|c|c|c|c|c|}
\hline Dimension & No. & Indicator & Description & Unit & Sign & Year & Source \\
\hline Health (A) & A1 & $\begin{array}{l}\text { Healthy life } \\
\text { expectancy at birth }\end{array}$ & $\begin{array}{l}\text { Average number of years that a person } \\
\text { can expect to live with "full health", } \\
\text { taking into account years lived with less } \\
\text { than full health due to disease and/or } \\
\text { injury }\end{array}$ & Years & $\operatorname{Max}$ & 2016 & $\begin{array}{l}\text { Word Health } \\
\text { Organization }\end{array}$ \\
\hline Health (A) & A2 & Health spending & $\begin{array}{c}\text { Final consumption of healthcare goods } \\
\text { and services including personal } \\
\text { healthcare and collective services but } \\
\text { excluding spending on healthcare } \\
\text { investments }\end{array}$ & $\begin{array}{l}\text { Percentage of } \\
\text { gross domestic } \\
\text { product }\end{array}$ & $\operatorname{Max}$ & 2019 & OECD \\
\hline Health (A) & A3 & $\begin{array}{l}\text { Available hospital } \\
\text { beds }\end{array}$ & $\begin{array}{l}\text { All hospital beds that are regularly } \\
\text { maintained and staffed and immediately } \\
\text { available for admitted patients' care }\end{array}$ & $\begin{array}{l}\text { Per } 100,000 \\
\text { inhabitants }\end{array}$ & $\operatorname{Max}$ & 2017 & Eurostat \\
\hline Health (A) & A 4 & HAQ Index & $\begin{array}{l}\text { Deaths from treatable health conditions } \\
\text { in } 195 \text { countries and regions }\end{array}$ & Score of $0-100$ & $\operatorname{Max}$ & 2015 & The Lancet \\
\hline $\begin{array}{l}\text { Education } \\
\text { (B) }\end{array}$ & B1 & $\begin{array}{l}\text { Population with } \\
\text { secondary } \\
\text { education }\end{array}$ & $\begin{array}{l}\text { Upper secondary and post-secondary } \\
\text { non-tertiary education among } \\
\text { individuals aged } 20 \text { to } 24\end{array}$ & Percentage & Max & 2019 & Eurostat \\
\hline $\begin{array}{l}\text { Education } \\
\text { (B) }\end{array}$ & B2 & $\begin{array}{l}\text { Population with } \\
\text { tertiary education }\end{array}$ & $\begin{array}{c}\text { Tertiary education for those aged } 25 \text { to } \\
64 \text { by gender and Nomenclature of } \\
\text { Territorial Units for Statistics (NUTS) } \\
2 \text { regions }\end{array}$ & Percentage & $\operatorname{Max}$ & 2019 & Eurostat \\
\hline $\begin{array}{l}\text { Education } \\
\text { (B) }\end{array}$ & B3 & PISA reading score & $\begin{array}{l}\text { Mean score and variation in reading } \\
\text { performance reported by PISA }\end{array}$ & Score & $\operatorname{Max}$ & 2018 & OECD \\
\hline $\begin{array}{l}\text { Education } \\
\text { (B) }\end{array}$ & $\mathrm{B} 4$ & $\begin{array}{l}\text { PISA mathematics } \\
\text { score }\end{array}$ & $\begin{array}{l}\text { Mean score and variation in } \\
\text { mathematics performance reported by } \\
\text { PISA }\end{array}$ & Score & $\operatorname{Max}$ & 2018 & OECD \\
\hline $\begin{array}{l}\text { Education } \\
\text { (B) }\end{array}$ & B5 & PISA science score & $\begin{array}{l}\text { Mean score and variation in science } \\
\text { performance reported by PISA }\end{array}$ & Score & $\operatorname{Max}$ & 2018 & OECD \\
\hline $\begin{array}{l}\text { Education } \\
\text { (B) }\end{array}$ & B6 & PISA total score & $\begin{array}{l}\text { Top performers in reading, mathematics, } \\
\text { and science reported by PISA }\end{array}$ & Percentage & $\operatorname{Max}$ & 2018 & OECD \\
\hline $\begin{array}{l}\text { Education } \\
\text { (B) }\end{array}$ & B7 & $\begin{array}{l}\text { QS World } \\
\text { University } \\
\text { Rankings }\end{array}$ & $\begin{array}{l}\text { Number of city's universities in the top } \\
500 \text { of QS ranking }\end{array}$ & Number & $\operatorname{Max}$ & 2019 & $\begin{array}{l}\text { QS top } \\
\text { universities }\end{array}$ \\
\hline $\begin{array}{l}\text { Employment } \\
\quad \text { and } \\
\text { income }(\mathrm{C})\end{array}$ & $\mathrm{C} 1$ & $\begin{array}{l}\text { Unemployment } \\
\text { rate }\end{array}$ & $\begin{array}{l}\text { Unemployment by gender for } \\
\text { individuals aged between } 15 \text { and } \\
74 \text {-annual data }\end{array}$ & $\begin{array}{l}\text { Percentage of } \\
\text { active } \\
\text { population }\end{array}$ & Min & 2019 & Eurostat \\
\hline $\begin{array}{l}\text { Employment } \\
\quad \text { and } \\
\text { income }(C)\end{array}$ & $\mathrm{C} 2$ & $\begin{array}{l}\text { Ease of doing } \\
\text { business ranking }\end{array}$ & $\begin{array}{l}\text { Economies ranked by ease of doing } \\
\text { business from 1-190 }\end{array}$ & Number & $\operatorname{Max}$ & 2019 & World Bank \\
\hline $\begin{array}{l}\text { Employment } \\
\quad \text { and } \\
\text { income }(\mathrm{C})\end{array}$ & C3 & Gini index & $\begin{array}{c}\text { Income dispersion value from } 0=\text { equal } \\
\text { income distribution to } 1=\text { total } \\
\text { inequality }\end{array}$ & Scale of $0-1$ & Min & $\begin{array}{l}2010- \\
2014\end{array}$ & OECD \\
\hline $\begin{array}{l}\text { Employment } \\
\quad \text { and } \\
\text { income }(\mathrm{C})\end{array}$ & $\mathrm{C} 4$ & $\begin{array}{l}\text { Number of work } \\
\text { hours/week }\end{array}$ & $\begin{array}{c}\text { Average number of usual weekly hours } \\
\text { of work in main job by gender, age, and } \\
\text { NUTS } 2 \text { region }\end{array}$ & Hours & Min & 2019 & Eurostat \\
\hline $\begin{array}{l}\text { Environment } \\
\text { (D) }\end{array}$ & D1 & $\begin{array}{l}\text { Density of airborne } \\
\text { particles } \\
\text { (particulate matter } \\
{[\mathrm{PM}] 2.5 \text { ) }}\end{array}$ & $\begin{array}{c}\text { Annual mean concentration of PM of } 2.5 \\
\text { microns or less in diameter (PM2.5) in } \\
\text { city and localities }\end{array}$ & $\begin{array}{l}\text { Grams/cubic } \\
\text { centimeter }\end{array}$ & Min & 2016 & $\begin{array}{l}\text { World Health } \\
\text { Organization }\end{array}$ \\
\hline $\begin{array}{l}\text { Environment } \\
\text { (D) }\end{array}$ & D2 & $\begin{array}{c}\text { Density of airborne } \\
\text { particles (PM 10) }\end{array}$ & $\begin{array}{c}\text { Annual mean concentration of PM of } \\
10 \text { microns or less in diameter (PM10) in } \\
\text { cities and localities }\end{array}$ & $\begin{array}{l}\text { Micrograms/cubic } \\
\text { meter }\end{array}$ & Min & 2017 & $\begin{array}{l}\text { World Health } \\
\text { Organization }\end{array}$ \\
\hline $\begin{array}{l}\text { Environment } \\
\text { (D) }\end{array}$ & D3 & $\begin{array}{l}\text { Greenhouse } \\
\text { emissions }\end{array}$ & $\begin{array}{c}\text { Total national emissions of greenhouse } \\
\text { gases including carbon dioxide, } \\
\text { methane, nitrous oxide, and so-called } \\
\text { fluorinated gases (i.e., } \\
\text { hydrofluorocarbons, perfluorocarbons, } \\
\text { nitrogen trifluoride, and sulfur } \\
\text { hexafluoride) }\end{array}$ & Tons per capita & Min & 2018 & Eurostat \\
\hline
\end{tabular}


Table 2. Cont.

\begin{tabular}{|c|c|c|c|c|c|c|c|}
\hline Dimension & No. & Indicator & Description & Unit & Sign & Year & Source \\
\hline $\begin{array}{l}\text { Environment } \\
\quad \text { (D) }\end{array}$ & D4 & Waste generation & $\begin{array}{l}\text { Waste generation by waste category, } \\
\text { hazardousness, and statistical } \\
\text { classification of economic activities or } \\
\text { NACE Rev. } 2\end{array}$ & $\begin{array}{l}\text { Kilograms per } \\
\text { capita }\end{array}$ & Min & 2016 & Eurostat \\
\hline $\begin{array}{l}\text { Environment } \\
\quad \text { (D) }\end{array}$ & D5 & Waste treatment & $\begin{array}{l}\text { Waste treatment by waste category, } \\
\text { hazardousness, and waste management } \\
\text { operations }\end{array}$ & $\begin{array}{l}\text { Kilograms per } \\
\text { capita }\end{array}$ & Max & 2016 & Eurostat \\
\hline $\begin{array}{l}\text { Environment } \\
\quad \text { (D) }\end{array}$ & D6 & $\begin{array}{l}\text { Energy from } \\
\text { renewable sources }\end{array}$ & Share of renewable energy & Percentage & Max & 2019 & Eurostat \\
\hline $\begin{array}{l}\text { Environment } \\
\quad \text { (D) }\end{array}$ & D7 & $\begin{array}{l}\text { Water for } \\
\text { consumption }\end{array}$ & $\begin{array}{l}\text { People using safely managed drinking } \\
\text { water services }\end{array}$ & Percentage & Max & 2017 & World Bank \\
\hline $\begin{array}{l}\text { Gender } \\
\text { equality } \\
\text { (E) }\end{array}$ & E1 & $\begin{array}{l}\text { Gender Equality } \\
\text { Index }\end{array}$ & $\begin{array}{l}\text { Composite indicator that quantifies the } \\
\text { progress made in implementation and } \\
\text { results of member states' equality } \\
\text { policies }\end{array}$ & Score & Max & 2019 & $\begin{array}{l}\text { European } \\
\text { Institute for } \\
\text { Gender } \\
\text { Equality }\end{array}$ \\
\hline $\begin{array}{l}\text { Gender } \\
\text { equality } \\
\text { (E) }\end{array}$ & E2 & $\begin{array}{l}\text { Global Gender Gap } \\
\text { Index }\end{array}$ & $\begin{array}{l}\text { (1) Economic participation and } \\
\text { opportunity: salaries, participation, and } \\
\text { highly qualified employment; } \\
\text { (2) education: access to basic and higher } \\
\text { levels of education; (3) political } \\
\text { participation: representation in } \\
\text { decision-making structures; (4) health } \\
\text { and survival: life expectancy and } \\
\text { male-female ratio }\end{array}$ & Score & Max & 2020 & $\begin{array}{l}\text { World } \\
\text { Economic } \\
\text { Forum }\end{array}$ \\
\hline $\begin{array}{l}\text { Gender } \\
\text { equality } \\
\text { (E) }\end{array}$ & E3 & $\begin{array}{l}\text { Gender Inequality } \\
\text { Index }\end{array}$ & $\begin{array}{l}\text { Three important aspects of human } \\
\text { development: reproductive health, } \\
\text { empowerment, and economic situation }\end{array}$ & $\begin{array}{l}\text { Score (the } \\
\text { lower the } \\
\text { better) }\end{array}$ & Min & 2019 & $\begin{array}{l}\text { Human } \\
\text { development } \\
\text { reports (United } \\
\text { Nations) }\end{array}$ \\
\hline Leisure (F) & $\mathrm{F} 1$ & $\begin{array}{l}\text { Theme Index and } \\
\text { Museum Index }\end{array}$ & $\begin{array}{l}\text { Number of museums in city that are in } \\
\text { the top } 20 \text { of Europe by visitors }\end{array}$ & Number & Max & 2019 & $\begin{array}{c}\text { Themed } \\
\text { Entertainment } \\
\text { Associa- } \\
\text { tion/AECOM }\end{array}$ \\
\hline Leisure (F) & F2 & $\begin{array}{l}\text { Restaurant Price } \\
\text { Index by city }\end{array}$ & $\begin{array}{l}\text { Comparison of prices of meals and } \\
\text { drinks in restaurants and bars to New } \\
\text { York City prices }\end{array}$ & Percentage & Min & 2020 & Numbeo \\
\hline Leisure (F) & F3 & $\begin{array}{l}\text { McMeal price at } \\
\text { McDonald's }\end{array}$ & $\begin{array}{l}\text { Price of McMeal or equivalent combo } \\
\text { meal by city }\end{array}$ & Euros & Min & 2020 & Numbeo \\
\hline Leisure (F) & F4 & $\begin{array}{c}\text { Number of } \\
\text { meetings per city }\end{array}$ & $\begin{array}{l}\text { European city ranking by number of } \\
\text { meetings }\end{array}$ & Number & Max & 2019 & ICCA \\
\hline Leisure (F) & F5 & $\begin{array}{l}\text { Number of parks } \\
\text { and natural sites }\end{array}$ & $\begin{array}{l}\text { Number of parks and natural sites in } \\
\text { city }\end{array}$ & Number & Max & 2020 & TripAdvisor \\
\hline Leisure (F) & F6 & $\begin{array}{l}\text { Number of } \\
\text { museums }\end{array}$ & Number of museums in city & Number & Max & 2020 & TripAdvisor \\
\hline Leisure (F) & F7 & $\begin{array}{l}\text { Number of } \\
\text { monuments and } \\
\text { interesting places } \\
\text { to visit in city }\end{array}$ & $\begin{array}{l}\text { Number of monuments and interesting } \\
\text { places in city }\end{array}$ & Number & Max & 2020 & TripAdvisor \\
\hline Leisure $(\mathrm{F})$ & F8 & Number of shows & $\begin{array}{l}\text { Number of shows in city including } \\
\text { theaters, comedy shows, and concerts }\end{array}$ & Number & Max & 2020 & TripAdvisor \\
\hline $\begin{array}{l}\text { Accommodati } \\
\text { and } \\
\text { security } \\
\text { (G) }\end{array}$ & G1 & Housing price & $\begin{array}{l}\text { Ratio between average housing prices } \\
\text { by city and average wage by country }\end{array}$ & Number & Min & 2020 & Numbeo \\
\hline $\begin{array}{l}\text { Accommodati } \\
\text { and } \\
\text { security } \\
\text { (G) }\end{array}$ & G2 & $\begin{array}{l}\text { Mortgage as } \\
\text { percentage of } \\
\text { income }\end{array}$ & $\begin{array}{l}\text { Ratio of actual monthly cost of } \\
\text { mortgage to take-home pay per family }\end{array}$ & Percentage & Min & 2020 & Numbeo \\
\hline
\end{tabular}


Table 2. Cont.

\begin{tabular}{|c|c|c|c|c|c|c|c|}
\hline Dimension & No. & Indicator & Description & Unit & Sign & Year & Source \\
\hline $\begin{array}{l}\text { Accommoda } \\
\text { and } \\
\text { security } \\
(G)\end{array}$ & G3 & $\begin{array}{l}\text { Price to rent ratio } \\
\text { in city center }\end{array}$ & $\begin{array}{l}\text { Average cost of ownership divided by } \\
\text { received rent income if buying to let or } \\
\text { estimated rent paid if buying to reside }\end{array}$ & Score & Min & 2020 & Numbeo \\
\hline $\begin{array}{l}\text { Accommoda } \\
\text { and } \\
\text { security } \\
\text { (G) }\end{array}$ & G4 & Crime rate index & $\begin{array}{l}\text { Estimation of overall level of crime in } \\
\text { city or country }\end{array}$ & Score & Min & 2020 & Numbeo \\
\hline $\begin{array}{l}\text { Accommoda } \\
\text { and } \\
\text { security } \\
(G)\end{array}$ & G5 & $\begin{array}{l}\text { Corruption } \\
\text { Perceptions Index }\end{array}$ & Perceived level of corruption by country & Number & Max & 2019 & $\begin{array}{l}\text { Transparency } \\
\text { International }\end{array}$ \\
\hline $\begin{array}{l}\text { Mobility } \\
(\mathrm{H})\end{array}$ & $\mathrm{H} 1$ & $\begin{array}{l}\text { Motor vehicle } \\
\text { traffic accidents }\end{array}$ & $\begin{array}{l}\text { Motor vehicle traffic accidents per } \\
100,000 \text { inhabitants }\end{array}$ & $\begin{array}{l}\text { Deaths per } \\
100,000\end{array}$ & Min & 2015 & $\begin{array}{l}\text { World Health } \\
\text { Organization }\end{array}$ \\
\hline $\begin{array}{l}\text { Mobility } \\
(\mathrm{H})\end{array}$ & $\mathrm{H} 2$ & Gasoline price & Price of one liter of gasoline by city & Euros & Min & 2020 & Numbeo \\
\hline $\begin{array}{l}\text { Mobility } \\
(\mathrm{H})\end{array}$ & H3 & $\begin{array}{l}\text { TomTom Traffic } \\
\text { Index }\end{array}$ & Level of urban congestion by city & Number & Max & 2019 & TomTom \\
\hline $\begin{array}{l}\text { Weather } \\
\text { (W) }\end{array}$ & $\mathrm{I} 1$ & Climate Index & $\begin{array}{l}\text { Includes average temperature, days of } \\
\text { rain, and total amount of rain in } \\
\text { millimeters by city }\end{array}$ & Number & Max & 2020 & Soler et al. [36] \\
\hline $\begin{array}{l}\text { Technology } \\
\text { (J) }\end{array}$ & $\mathrm{J} 1$ & $\begin{array}{l}\text { Innovation Cities } \\
\text { Index }\end{array}$ & $\begin{array}{l}\text { Values ranging from } 0=\text { no innovation } \\
\text { to } 60=\text { much innovation }\end{array}$ & Number & Max & 2019 & $\begin{array}{l}\text { Innovation } \\
\text { Cities Program }\end{array}$ \\
\hline $\begin{array}{l}\text { Technology } \\
(J)\end{array}$ & $\mathrm{J} 2$ & Web Index & $\begin{array}{l}\text { Economic, social, and political benefit } \\
\text { that countries obtain from the Internet }\end{array}$ & Number & $\operatorname{Max}$ & $\begin{array}{c}2014- \\
15\end{array}$ & $\begin{array}{l}\text { World Wide } \\
\text { Web } \\
\text { Foundation }\end{array}$ \\
\hline $\begin{array}{l}\text { Technology } \\
\text { (J) }\end{array}$ & $\mathrm{J} 3$ & Internet speed & Internet speed by city & Mbps & Max & 2020 & Nomad List \\
\hline $\begin{array}{l}\text { Technology } \\
(J)\end{array}$ & $\mathrm{J} 4$ & Internet access & $\begin{array}{l}\text { Households with access to Internet at } \\
\text { home }\end{array}$ & Percentage & Max & 2019 & Eurostat \\
\hline $\begin{array}{l}\text { Technology } \\
(J)\end{array}$ & $\mathrm{J} 5$ & Broadband access & $\begin{array}{l}\text { Households with broadband access by } \\
\text { NUTS } 2 \text { region }\end{array}$ & Percentage & Max & 2019 & Eurostat \\
\hline $\begin{array}{l}\text { Technology } \\
(J)\end{array}$ & $\mathrm{J} 6$ & $\begin{array}{l}\text { Global Innovation } \\
\text { Index }\end{array}$ & $\begin{array}{l}\text { Latest trends and annual innovation } \\
\text { ranking of } 131 \text { economies by country }\end{array}$ & Score $(0-100)$ & Max & 2020 & WIPO \\
\hline
\end{tabular}

Note: Max = maximum; Min = minimum.

\subsection{Methodology}

\subsubsection{Factor Analysis}

The complexity of multidimensional analysis means that the number of indicators for each criterion needs to be minimized. To this end, the present study conducted Exploratory factor analysis (EFA), which is used to confirm empirically the conceptual structure established in advance and the role that each element plays in the overall decision-support system. This technique was considered especially relevant to this research given the large number of indicators initially selected.

Exploratory factor analysis uses statistics to explain the covariances or correlations between observed or measured criteria through a reduced set of latent variables or factors [48]. In the current study, this step relied on principal component analysis (PCA). Additional statistical tools applied were Kaiser-Meyer-Olkin index, Bartlett's test of sphericity, and an anti-image correlation matrix.

A factor analysis was performed with the principal components method and a Varimax orthogonal rotation. Using this technique, the structures constituted by the factors could be identified [49]. In addition, the discharge of Cronbach [50] was used to measure the reliability of the measurement scale. In the same way, to evaluate the validity of the constructs, the Kaiser-Meyer-Olkin (KMO) sample adequacy test and the Bartlett sphericity test were used to see the convenience of applying factor analysis on the variables [51]. The 
KMO test helped determine the advisability of adapting the factorial model. The value of the Bartlett sphericity test can refute the hypothesis of initially uncorrelated variables [52]. The matrix of rotated components helped to show the items in the factors indicated in the model, showing factorial loads close to +1 or -1 according to the orthogonal rotation model used. When the weights are closer to +1 or -1 there will be a greater link between the item and the factor $[49,53]$.

\subsubsection{AHP Method}

The AHP was used to determinate each criterion's weight [8]. This method can address complex decision-making problems involving variables and qualitative data that are difficult to assess. The AHP assumes that people can more easily make pairwise comparisons than overall comparisons, so this method starts with constructing a paired comparison table. Thus, each criterion is evaluated with reference to each of the other variables. The decision makers assign a score from 1 to 9 to each criterion through pairwise comparisons, which eventually produces a comparison matrix.

This matrix respects the properties of reciprocity (i.e., if $a_{i j}=x$, then $a_{j i}=1 / x$ ), homogeneity (i.e., if $i$ and $j$ are equally important, $a_{i j}=a_{j i}=1$ and $a_{i i}=1$ for all $i$ ), and consistency (i.e., the matrix must not include any contradictions in the valuation's results). The latter is verified using a consistency ratio whose value, depending on the matrix's size, must not exceed a specific percentage. In the present study, this ratio could not exceed $10 \%$.

Once the results' consistency was verified, the weights were estimated to represent each criterion's relative importance or the priority given the different alternatives involving each criterion. To do this, the AHP uses mathematical techniques of linear algebra (i.e., eigenvalues method) based on Equation (1):

$$
A \times w=\lambda_{\max } \times w
$$

in which $A$ represents the comparison matrix, $w$ is the eigenvector or preference vector, and $\lambda_{\max }$ stands for the maximum eigenvalue of matrix $A$.

\subsubsection{PROMETHEE}

This research relied on the PROMETHEE, which was first developed by Brans [54] and then extended by Vincke and Brans [7]. The PROMETHEE belongs to the outranking family of methods. Various studies in the literature have confirmed that the PROMETHEE is a reliable MCDM method. In addition, many researchers have reported interesting results with applications of the PROMETHEE in tourism, management, financial areas, and logistics. Among the tourism studies, those worth highlighting include regional tourism competitiveness [25] and hotel website evaluations [26].

Two versions of this method are available: PROMETHEE I and PROMETHEE II. The difference between them is that while the PROMETHEE I shows partial classifications that can include incomparability, the PROMETHEE II produces a complete ranking of alternatives. The current research needed a complete ranking, so the PROMETHEE II was applied. The analysis was completed using the GAIA technique, which provides a geometrical representation of PROMETHEE results.

To apply the PROMETHEE II, the alternatives identified were subjected to a pairwise comparison of each criterion based on the decision makers' preferences, thereby creating a scores matrix. These scores were then added to produce a complete ranking. To ensure a fuller understanding of this method, it can be divided into five steps.

\section{Step One}

The first step is to make pairwise comparisons and construct a preference matrix. Given a problem with $m$ possible alternatives, $A=\left\{a_{1}, a_{2}, a_{3}, \ldots, a_{m}\right\}$. In addition, given $k$ criteria to evaluate the alternatives, $F=\left\{f_{1}, f_{2}, f_{3}, \ldots f_{k}\right\}$. The criteria can also have different weights, which, in the present study, were assigned using the AHP method previously described. 
For each criterion, the decision makers choose which alternative is preferable between $a$ and $b$ with reference to the differences between previous evaluations, as shown in Equation (2):

$$
P(a, b)=f_{j}(a)-f_{j}(b), \forall a, b \in A
$$

The aggregate preference index $\pi(a, b) \forall a, b \in A$ expresses how much $a$ is preferred to $b$ as shown in Equation (3):

$$
\pi(a, b)=\sum_{j=1}^{k} P_{j}(a, b) \times w_{j}
$$

in which $w_{j}$ are each criterion's weights. The degree of preference is valued on a scale of 0 to 1 .

\section{Step Two}

This second step focuses on finding the best preference function. To obtain the decision makers' degree of preference, a function is chosen from among various typical options. Depending on the chosen function, specific parameters need to be defined [28].

In the present research, a linear function was chosen with an indifference zone. To apply this function, two parameters were considered: the indifference parameter $q$ and preference parameter $p$. The indifference parameter $q$ was set at $5 \%$, which means that the value of $q$ would be $5 \%$ of the difference between the highest and lowest evaluations for each criteria. The preference parameter $p$ was fixed at $60 \%$ so that $p$ would be $60 \%$ of the difference between the maximum and minimum values assigned each criterion [55]. The calculations are denoted, respectively, by Equations (4) and (5):

$$
\begin{aligned}
& \forall j q_{j}=0.05 \times\left[\max \left(g_{i}\right)-\min \left(g_{i}\right)\right] \\
& \forall j p_{j}=0.60 \times\left[\max \left(g_{i}\right)-\min \left(g_{i}\right)\right]
\end{aligned}
$$

The function with linear preference and indifference zones is formally described by Equation (6):

$$
P_{j}(a, b)=\left\{\begin{array}{c}
0 \text { if } d_{j} \leq q_{j} \\
\frac{d_{j-} q_{j}}{p_{j}-q_{j}} \text { if } q_{j}<d_{j} \leq p_{j} \\
1 \text { if } d_{j}>p_{j}
\end{array}\right.
$$

This function is represented as a graph in Figure 2.

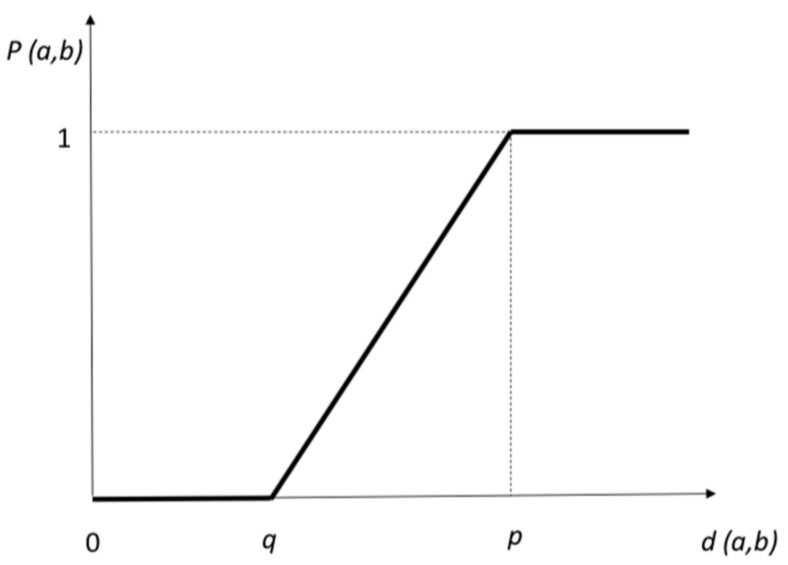

Figure 2. Linear function with indifference zone.

Step Three

The PROMETHEE I provides a partial ranking of the alternatives based on each option's positive $\varphi^{+}(a)$ and negative flows $\varphi^{-}(a)$. The positive flow represents how much alternative $a$ is preferred to the remaining options. The higher the value of $\varphi^{+}(a)$, the better the alternative. The negative flow expresses how much alternative $a$ is outranked by the other choices. The smaller $\varphi^{-}(a)$, the better the alternative This ranking procedure can be expressed more formally as Equations (7) and (8): 


$$
\begin{aligned}
\varphi^{+}(a) & =\frac{1}{m-1} \sum_{x \in A} \pi(a, x) \\
\varphi^{-}(a) & =\frac{1}{m-1} \sum_{x \in A} \pi(x, a)
\end{aligned}
$$

\section{Step Four}

The PROMETHEE II pinpoints the net outranking flow values to facilitate a complete ranking of the alternatives. Net outranking flow is defined as the difference between positive and negative flows. In the PROMETHEE II, all the alternatives are comparable [28], as shown in Equation (9):

$$
\varphi(a)=\varphi^{+}(a)-\varphi^{-}(a)
$$

If $\varphi(a)>\varphi(b)$, then alternative $a$ outranks $b$ for all criteria.

\section{Step Five}

The GAIA plane is a graphical tool that uses PCA to visualize the relative position of each alternative based on its contribution to the different criteria considered. GAIA represents the options on a plane as points and the criteria as axes, whose length indicate their weight or importance within the decision problem. The weights are also represented in the plane by a vector that indicates the decision makers' priorities.

Conclusions can be drawn based on this visual analysis. The alternatives located close to each other present similar types of development paths or actions, while the more distant ones indicate contrasting ways to develop solutions. The visual representation's quality is indicated by the delta parameter, which denotes the amount of information reflected in the GAIA plane [25,28]. According to Brans and Mareschal [56], real-life GAIA applications should produce a delta parameter higher than $60 \%$ or higher than $80 \%$ in some cases. This level of detail means that, even with a large number of criteria, the GAIA plane can provide reliable information.

\section{Results}

In the present study, 66 European cities were compared using the criteria previously described. The factor analysis's results confirmed that the accommodations and security dimension needed to be divided into the separate variables of accommodations and security. Thus, 11 criteria or dimensions were considered in the final analyses: health, education, employment, environment, equality, leisure, accommodations, security, mobility, climate, and technology. The process assigned a weight to each indicator and, finally, reduced them down to one for each criterion.

Factor Analysis has had several stages. First, the correlation matrix was calculated between all the variables used. The conditions for applying this technique were examined, that is, that the variables were highly correlated, but in turn presented heterogeneous data. The necessary factors were then extracted. Then the factor rotation was given and finally the factor scores were calculated, creating a new variable that encompassed each dimension.

The reliability of the scale of measurement was used the Cronbach's alpha. Their results were higher than 0.7 , so it can be said that they are at acceptable levels. The results are presented in Appendix A (Table A1). In relation to the results of the factor analysis, the $\mathrm{KMO}$ test yielded a value of 0.912 . Since the value is close to 1 , the data are susceptible to variable reduction through factor analysis. Bartlett's sphericity test contrasted the null hypothesis that the correlation matrix is an identity matrix. The null hypothesis was rejected since the $p$-value is less than 0.05 , determining the adequacy of the data to the factor analysis. The matrix of rotated components is compiled in Appendix A (Table A2). From this information the dimensions were generated. 
The AHP method was applied to weight the criteria. During this part of the process, a group of recruited experts jointly used the AHP to define the weights for the current decision problem.

The three authors of the present work chose a panel of experts with some considerations. The criteria for the selection of experts has been that they should be people with recognized experience in the management of organizations linked to the dimension studied or university professors who investigate that dimension. For each of the dimensions, there should be at least 3 experts who, together with the three authors, will analyze each of the dimensions. In total we worked with 30 experts plus the 3 authors of the present work. In health, 2 hospital managers and a manager of a nursing home. Regarding education, there was a primary school teacher, a secondary school teacher, and a university professor (in addition to the authors of this study, university professors). Regarding employment, we worked with a politician with responsibilities in this area plus two university professors who are experts in this area. In terms of the environment, there were 2 entrepreneurs from environmental consulting firms and a service manager from the local environmental administration. In terms of gender and equality, 2 people who work in the local administration and one in the regional administration in this area. As an expert in the Leisure dimension, there were two restaurant managers and a museum director. In accommodation and security we worked with 2 hotel managers and a policeman. In mobility, the experts were two policemen and a politician from that area. In the Weather area, the experts were 3 university geography professors. Finally, in Technology, we worked with 3 university engineering professors.

Once the panel of experts was formed, the Delphi research method was used. Expert estimates are made in successive rounds, anonymously, in an attempt to reach consensus.

The weights vector was obtained and incorporated into the analyses. The results are shown in Table 3. The associated comparison matrix has a consistency index of $8.2 \%$.

Table 3. AHP priority ranking.

\begin{tabular}{ccc}
\hline Dimensions & Priority & Rank \\
\hline Security & $21.61 \%$ & 1 \\
Technology & $15.18 \%$ & 2 \\
Education & $13.21 \%$ & 4 \\
Equality & $11.14 \%$ & 5 \\
Health & $10.61 \%$ & 6 \\
Employment & $8.63 \%$ & 7 \\
Climate & $5.82 \%$ & 8 \\
Housing & $4.45 \%$ & 9 \\
Mobility & $3.18 \%$ & 10 \\
Leisure & $3.14 \%$ & 11 \\
Environment & $3.03 \%$ & 10 \\
Total & $100.00 \%$ & \\
\hline
\end{tabular}

Note: Consistency ratio $=8.2 \%$.

Notably, the comparisons between dimensions were made from the perspective of business investments rather than accommodations, quality of life, or tourists' interests. This means that the ordering of the dimensions was done thinking about what the most important thing that the city should have is according to the managers to locate their company. Dimensions such as security and technology are thus a priority for company managers, while the environment and leisure dimensions are less important. The latter findings imply that the weights could change if the decision makers' comparisons had been based on a different decision problem than where to locate business investments.

Finally, after the PROMETHEE II was applied, the results reveal that London is the best positioned city, followed by Paris and Barcelona. At the bottom of the ranking are Riga, Vilnius, and Zagreb. The intermediate positions are filled by Seville, Malaga, Helsinki, and Hamburg, among others. The final ranking is presented in Table 4. A significant 
distance was detected between the first two cities (i.e., London and Paris) and the third in the ranking (i.e., Barcelona), which highlights the marked differences between them.

Table 4. Final ranking.

\begin{tabular}{|c|c|c|c|c|c|c|c|c|c|c|c|c|c|c|}
\hline Rank & Alternative & Phi & Phi+ & Phi- & Rank & Alternative & Phi & Phi+ & Phi- & Rank & Alternative & Phi & Phi+ & Phi- \\
\hline 1 & London & 0.3478 & 0.3899 & 0.0421 & 23 & Liverpool & 0.0444 & 0.1592 & 0.1148 & 45 & Valleta & -0.0514 & 0.1426 & 0.194 \\
\hline 2 & Paris & 0.318 & 0.3564 & 0.0384 & 24 & Valencia & 0.0381 & 0.1801 & 0.1419 & 46 & The Hague & -0.0568 & 0.1611 & 0.2179 \\
\hline 3 & Barcelona & 0.1866 & 0.2445 & 0.0578 & 25 & Amsterdam & 0.038 & 0.2063 & 0.1683 & 47 & Prague & -0.0652 & 0.1367 & 0.202 \\
\hline 4 & Stockholm & 0.1678 & 0.268 & 0.1003 & 26 & Turin & 0.0348 & 0.2126 & 0.1777 & 48 & Vienna & -0.0682 & 0.1284 & 0.1966 \\
\hline 5 & Marseille & 0.1671 & 0.2378 & 0.0707 & 27 & Sevilla & 0.0339 & 0.1709 & 0.1371 & 49 & Copenhagen & -0.0753 & 0.1632 & 0.2385 \\
\hline 6 & Bilbao & 0.1476 & 0.227 & 0.0794 & 28 & Malaga & 0.0295 & 0.1738 & 0.1443 & 50 & Munich & -0.0822 & 0.1498 & 0.232 \\
\hline 7 & Madrid & 0.1447 & 0.2265 & 0.0818 & 29 & Helsinki & 0.0275 & 0.232 & 0.2046 & 51 & Oporto & -0.0876 & 0.1137 & 0.2013 \\
\hline 8 & Gothenburg & 0.1387 & 0.2505 & 0.1117 & 30 & Hamburg & 0.0221 & 0.1487 & 0.1266 & 52 & Budapest & -0.0996 & 0.1752 & 0.2748 \\
\hline 9 & Rome & 0.1383 & 0.269 & 0.1307 & 31 & Leeds & 0.0192 & 0.1518 & 0.1326 & 53 & Ljubljana & -0.1035 & 0.0874 & 0.1909 \\
\hline 10 & Birmingham & 0.1119 & 0.2086 & 0.0967 & 32 & Cologne & 0.0137 & 0.1447 & 0.131 & 54 & Sofia & -0.1081 & 0.2024 & 0.3104 \\
\hline 11 & Manchester & 0.1009 & 0.1947 & 0.0938 & 33 & Reykjavik & 0.0069 & 0.2085 & 0.2016 & 55 & Aarhus & -0.1206 & 0.152 & 0.2726 \\
\hline 12 & Athens & 0.0938 & 0.2918 & 0.198 & 34 & Belfast & 0.0043 & 0.1492 & 0.1449 & 56 & Katowice & -0.1285 & 0.1226 & 0.2511 \\
\hline 13 & Milan & 0.0911 & 0.2243 & 0.1332 & 35 & Zaragoza & 0.002 & 0.1605 & 0.1585 & 57 & Warsaw & -0.1438 & 0.1135 & 0.2573 \\
\hline 14 & Dublin & 0.0869 & 0.1865 & 0.0997 & 36 & Thessaloniki & 0.0017 & 0.2339 & 0.2322 & 58 & Brno & -0.1739 & 0.0714 & 0.2453 \\
\hline 15 & Naples & 0.0738 & 0.2553 & 0.1814 & 37 & Lisbon & -0.0026 & 0.1469 & 0.1495 & 59 & Krakow & -0.1752 & 0.0862 & 0.2614 \\
\hline 16 & Lyon & 0.073 & 0.1658 & 0.0928 & 38 & Edinburgh & -0.0033 & 0.1564 & 0.1596 & 60 & Bucharest & -0.1786 & 0.135 & 0.3136 \\
\hline 17 & Brussels & 0.066 & 0.1694 & 0.1034 & 39 & Cardiff & -0.0044 & 0.1471 & 0.1515 & 61 & Bratislava & -0.1828 & 0.0981 & 0.2809 \\
\hline 18 & Berlin & 0.0647 & 0.1845 & 0.1198 & 40 & Rotterdam & -0.0046 & 0.1725 & 0.177 & 62 & Plovdiv & -0.1857 & 0.1682 & 0.3538 \\
\hline 19 & Toulouse & 0.0575 & 0.1634 & 0.1059 & 41 & Luxembourg & -0.0073 & 0.1738 & 0.181 & 63 & Tallinn & -0.1934 & 0.0886 & 0.282 \\
\hline 20 & Lille & 0.0558 & 0.1673 & 0.1115 & 42 & Palermo & -0.0092 & 0.2046 & 0.2138 & 64 & Riga & -0.1992 & 0.0929 & 0.2921 \\
\hline 21 & Murcia & 0.0557 & 0.1841 & 0.1284 & 43 & Antwerp & -0.0327 & 0.1214 & 0.1542 & 65 & Zagreb & -0.2234 & 0.0816 & 0.3049 \\
\hline 22 & Glasgow & 0.0482 & 0.1628 & 0.1146 & 44 & Nicosia & -0.0499 & 0.1489 & 0.1988 & 66 & Vilnius & -0.2349 & 0.0681 & 0.3031 \\
\hline
\end{tabular}

Note: Phi $=$ flow.

Figure 3 shows the results of the partial ranking obtained with the PROMETHEE I, which represents the positive (Phi+) and negative (Phi-) flows of the 66 cities. London, Paris, and Athens are at the top, listed here from higher to lower positive flows, while the lowest of all negative flows correspond to Paris, London, and Barcelona.

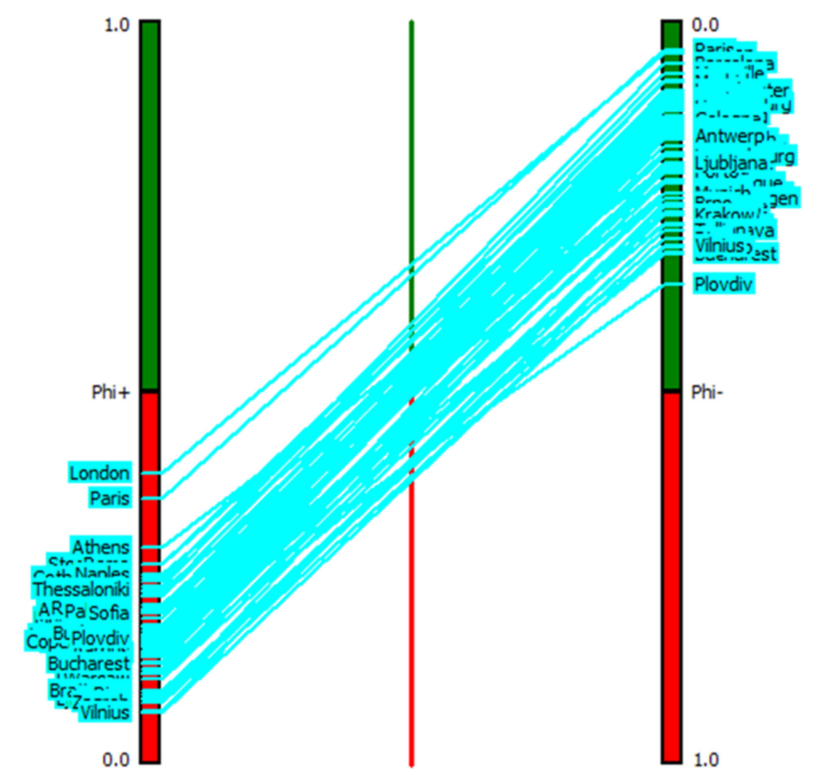

Figure 3. Partial ranking with PROMETHEE I.

Figure 4 presents the net flow graph generated using the PROMETHEE II. The first positions in the ranking are occupied by London, Paris, and Barcelona, in order by strongest flow. As mentioned previously, the results reveal a large distance between the first two positions (i.e., London and Paris) and the third (i.e., Barcelona), but the differences between the rest of the cities is less noticeable. 


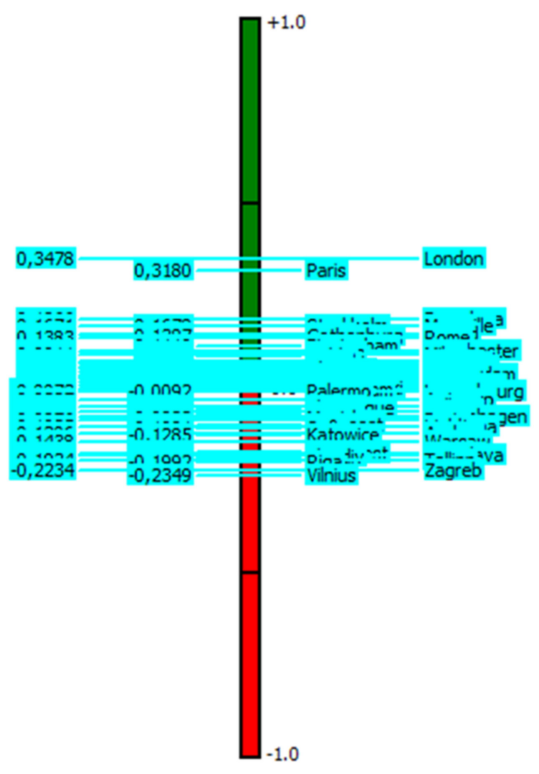

Figure 4. Final ranking with PROMETHEE II.

Based on the bar graphs of six cities in Figure 5, the best positioned metropolises in the ranking, that is, London, Paris, and Barcelona, present high positive flows in practically all dimensions. In contrast, the other three cities of Riga, Zagreb, and Vilnius have negative flows for almost all the variables.
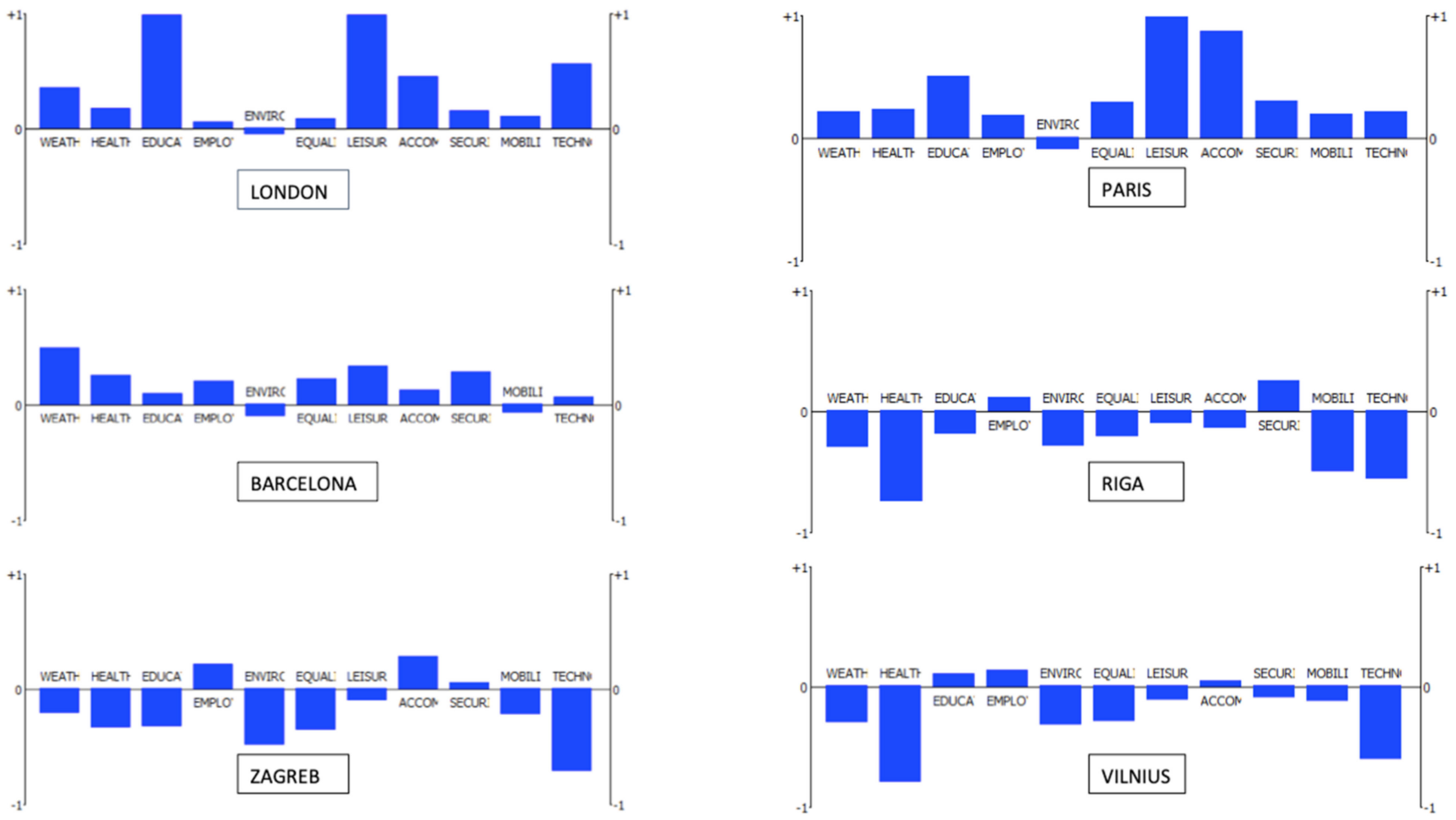

Figure 5. Bar charts.

The GAIA plane in Figure 6 reveals that cities such as London, Paris, Stockholm, or Toulouse have similar patterns in health, mobility, equality, and leisure criteria. Barcelona, Malaga, Seville, Marseille, Murcia, and Lisbon are grouped around weather and security factors. The environment, technology, and education criteria are similar in other cities, for example, Berlin, Brussels, or Helsinki. 


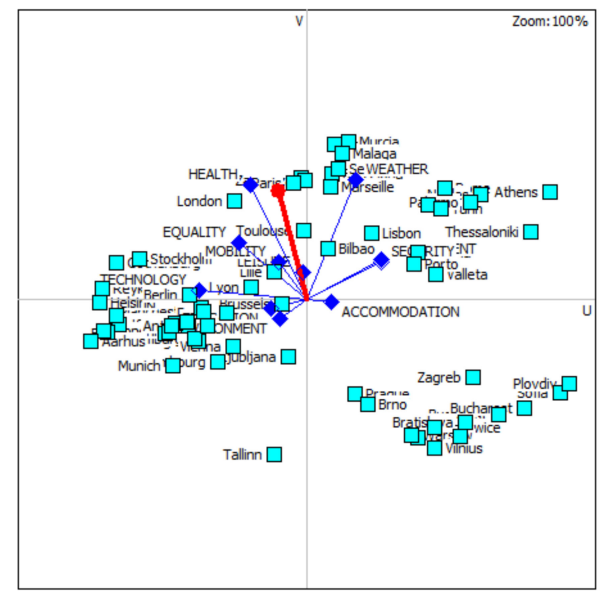

Figure 6. GAIA plane.

In addition, the above figure clearly displays the most distant cities in terms of all the criteria, with the worst positioned including, among others, Zagreb, Vilnius, Plovdiv, Sofia, and Katowice. The axis in red is the decision axis around which the best positioned cities in this study are located. The delta parameter is $64 \%$, which is above the $60 \%$ suggested by Brans and Mareschal [51] as an acceptable value in real-life GAIA applications. Thus, the above GAIA plane provides reliable information, visually representing the differences and similarities between cities according to the different criteria selected.

\section{Discussion}

The findings of this work illuminate in several aspects, among them, the dimensions dealt with and their importance in the location of a company. The AHP method served to have a very clear idea of what the dimensions are that are valued in the location of a company. First of all, the most important is safety. Company location destinations where there is no security are not chosen by companies to locate their production plant. If the companies still need to be strategically in that location, then they will choose different entry modes such as alliances, reducing the risk of the operation. Second, technology and education are also important factors. Good computer connections, a broadband network, together with a high education, especially in technology, will be very important. Equality, health, and employment will be very important. On the other hand, curiously, the least important will be the environment, followed by the leisure offer, mobility, housing, or the climate.

The above results were then compared with those obtained by other similar indices. The ECQI [6] also assigns the first position in the ranking to London, but Paris is in ninth place. Berlin comes in third, even though this city is ranked eighteenth in the present study's final ranking. These differences could be due to the inclusion of climate and technology dimensions that are not part of the ECQI, and to the different methodologies and approaches used to weight the criteria. While the ECQI focuses more on cities' quality of life, the current research was designed to reflect a business or investment perspective.

In the Cities in Motion Index ranking [5], London also appears in first place, followed by New York and Amsterdam in third position. Paris comes second in the present study's ranking, but, in the cited ranking, this metropolis is in fourth place. The Cities in Motion Index, however, compares more than 100 cities worldwide, while the current study concentrated on European cities.

Finally, the results were compared with the Global Power City Index [4], whose ranking places London first, New York second, Tokyo third, and Paris fourth. The cited index is clearly a worldwide ranking that focuses on cities' power to attract people, capital, and companies. 


\section{Conclusions}

This section summarizes the present research's main theoretical and practical contributions. The main limitations are also discussed, and future lines of research are outlined.

\subsection{Theoretical Implications}

The decision of where to locate investments or businesses is of strategic importance and key to the survival and development of companies, so this is still one of the main problems managers must resolve within their companies' expansion and internationalization strategies. A multitude of factors come into play in this type of decision, indicating that it should be treated as a multi-criteria decision problem. For this we have addressed the problem considering the main criteria that must be taken into account when facing the decision, taking as a reference base different index found in the academic literature, specifically the Cities in Motion, the ECQI and the Global Power Index. By incorporating a mathematical methodology in decision-making, arbitrariness is reduced, increasing the chances of success and allowing an improvement in decision-making of this type. This study thus applied appropriate mathematical techniques, namely, the PROMETHEE and the AHP method, to help decision makers make better choices. With these techniques it is possible to obtain a ranking of preferences between different locations (cities in our empirical case), which allows showing the relative position between them and also the state of each city in each of the criteria. The weighting vector can be changed according to the decision-maker's preferences, but always subject to the consistency parameter provided by the AHP method, all of which allows obtaining different classifications based on the decision-maker and his preferences.

\subsection{Practical Implications}

The proposed methodology can serve as a decision-support tool for managers seeking to determine the most strategic location for their business and/or investments. The results offer a preferential ranking of 66 major European cities based on multiple criteria with a purely business focus.

\subsection{Limitations and Future Lines of Research}

This study's main limitations included the difficulty of obtaining disaggregated data at the city level for the different dimensions and variables. The data had to be drawn from multiple sources such as the Gender Inequality Index (i.e., equality criteria), Global Innovation Index (i.e., technology criteria), and Perception of Corruption Index (i.e., security criteria). In addition, although this research relied on the AHP method to weight the criteria, this tool is not the only valid option in this context, as expert panels or other methods could also be applied.

Nonetheless, the combination of methodologies used in this study could also prove useful in the social sphere, as long as the proposed approach is adapted appropriately when making comparisons between dimensions. The results could include another ranking of cities according to better quality of life or tourism prospects. As indicated in the PROMETHEE methodology subsection, the choice was made to use a linear preference function with an indifference zone. In future research, another preference function such as the Gaussian function could be selected, and the results could be compared with the present study's findings.

Author Contributions: Conceptualization, V.P.-B., G.G. and M.H.; methodology, V.P.-B., G.G. and M.H.; software, V.P.-B., G.G. and M.H.; validation, V.P.-B., G.G. and M.H.; formal analysis, V.P.-B., G.G. and M.H.; investigation, V.P.-B., G.G. and M.H.; resources, V.P.-B., G.G. and M.H.; data curation, V.P.-B., G.G. and M.H.; writing-original draft preparation, V.P.-B., G.G. and M.H.; writing-review and editing, V.P.-B., G.G. and M.H.; visualization, V.P.-B., G.G. and M.H.; supervision, V.P.-B., G.G. and M.H.; project administration, V.P.-B., G.G. and M.H. All authors have read and agreed to the published version of the manuscript. 
Funding: This research received no external funding.

Institutional Review Board Statement: Not applicable.

Informed Consent Statement: Not applicable.

Data Availability Statement: The data presented in this study are available on request from the corresponding author.

Conflicts of Interest: The authors declare no conflict of interest.

\section{Appendix A}

Table A1. Internal reliability (Cronbach's alpha).

\begin{tabular}{|c|c|c|}
\hline Dimension & Tag & Cronbach's Alpha \\
\hline Health & $\begin{array}{l}\text { A1 } \\
\text { A2 } \\
\text { A3 } \\
\text { A4 }\end{array}$ & 0.764 \\
\hline Education & $\begin{array}{l}\text { B3 } \\
\text { B4 } \\
\text { B5 } \\
\text { B6 }\end{array}$ & 0.874 \\
\hline Employment and Income & $\begin{array}{l}\mathrm{C} 1 \\
\mathrm{C} 2 \\
\mathrm{C} 3 \\
\mathrm{C} 4\end{array}$ & 0.815 \\
\hline Environment & $\begin{array}{l}\text { D3 } \\
\text { D4 } \\
\text { D5 }\end{array}$ & 0.747 \\
\hline Gender and Equality & $\begin{array}{l}\text { E1 } \\
\text { E2 } \\
\text { E3 }\end{array}$ & 0.715 \\
\hline Leisure & $\begin{array}{l}\text { F1 } \\
\text { F4 } \\
\text { F5 } \\
\text { F6 } \\
\text { F7 } \\
\text { F8 }\end{array}$ & 0.876 \\
\hline Accommodation & $\begin{array}{l}\text { G1 } \\
\text { G2 } \\
\text { G3 }\end{array}$ & 0.700 \\
\hline Security & $\begin{array}{l}\text { G4 } \\
\text { G5 }\end{array}$ & 0.730 \\
\hline Mobility & $\begin{array}{l}\mathrm{H} 1 \\
\mathrm{H} 2\end{array}$ & 0.920 \\
\hline Technology & $\begin{array}{l}\mathrm{J} 1 \\
\mathrm{~J} 2 \\
\mathrm{~J} 4 \\
\mathrm{~J} 5 \\
\mathrm{~J} 6\end{array}$ & 0.863 \\
\hline
\end{tabular}


Table A2. Matrix of rotated components.

\begin{tabular}{|c|c|c|c|c|c|c|c|c|c|c|}
\hline & 1 & 2 & 3 & 4 & 5 & 6 & 7 & 8 & 9 & 10 \\
\hline A1 & 0.961 & & & & & & & & & \\
\hline A2 & 0.675 & & & & & & & & & \\
\hline A3 & -0.749 & & & & & & & & & \\
\hline A 4 & 0.918 & & & & & & & & & \\
\hline B3 & & 0.921 & & & & & & & & \\
\hline B4 & & 0.953 & & & & & & & & \\
\hline B5 & & 0.991 & & & & & & & & \\
\hline B6 & & 0.915 & & & & & & & & \\
\hline $\mathrm{C} 1$ & & & 0.590 & & & & & & & \\
\hline $\mathrm{C} 2$ & & & 0.743 & & & & & & & \\
\hline $\mathrm{C} 3$ & & & 0.708 & & & & & & & \\
\hline $\mathrm{C} 4$ & & & 0.663 & & & & & & & \\
\hline D3 & & & & 0.542 & & & & & & \\
\hline D4 & & & & 0.967 & & & & & & \\
\hline D5 & & & & 0.972 & & & & & & \\
\hline E1 & & & & & 0.936 & & & & & \\
\hline E2 & & & & & 0.861 & & & & & \\
\hline E3 & & & & & -0.786 & & & & & \\
\hline F1 & & & & & & 0.830 & & & & \\
\hline $\mathrm{F} 4$ & & & & & & 0.814 & & & & \\
\hline F5 & & & & & & 0.957 & & & & \\
\hline F6 & & & & & & 0.922 & & & & \\
\hline F7 & & & & & & 0.891 & & & & \\
\hline F8 & & & & & & 0.964 & & & & \\
\hline G1 & & & & & & & 0.974 & & & \\
\hline $\mathrm{G} 2$ & & & & & & & 0.927 & & & \\
\hline G3 & & & & & & & 0.745 & & & \\
\hline G4 & & & & & & & & 0.713 & & \\
\hline G5 & & & & & & & & -0.713 & & \\
\hline $\mathrm{H} 1$ & & & & & & & & & 0.793 & \\
\hline $\mathrm{H} 2$ & & & & & & & & & -0.793 & \\
\hline $\mathrm{J} 1$ & & & & & & & & & & 0.601 \\
\hline $\mathrm{J} 2$ & & & & & & & & & & 0.891 \\
\hline $\mathrm{J} 4$ & & & & & & & & & & 0.933 \\
\hline $\mathrm{J} 5$ & & & & & & & & & & 0.899 \\
\hline J6 & & & & & & & & & & 0.905 \\
\hline
\end{tabular}

\section{References}

1. Chang, X.; Li, J. Business performance prediction in location-based social commerce. Expert Syst. Appl. 2019, 126, 112-123. [CrossRef]

2. Arauzo-Carod, J.M.; Liviano-Solis, D.; Manjón-Antolín, M.C. Empirical studies in industrial location: An assessment of their methods and results. J. Reg. Sci. 2010, 50, 685-711. [CrossRef]

3. Button, P. Do tax incentives affect business location and economic development? Evidence from state film incentives. Reg. Sci. Urban Econ. 2019, 77, 315-339. [CrossRef] [PubMed]

4. The Mori Memorial Foundation. Global Power City Index; Mori Memorial Foundation: Tokyo, Japan, 2020.

5. IESE Business School. Cities in Motion Index; IESE Business School: Pamplona, Navarra, Spain, 2019.

6. Fernandez-Crehuet, J.M.; Rosales-Salas, J.; Avilés, R. Best city to invest in: European Cities Quality Index. Risk Gov. Control. Financ. Mark. Inst. 2020, 10, 8-22. [CrossRef]

7. Brans, J.-P.; Vincke, P. Note-A Preference Ranking Organisation Method: (The PROMETHEE Method for Multiple Criteria Decision-Making). Manag. Sci. 1985, 31, 647-656. [CrossRef]

8. Saaty, T.L. The Analytic Hierarchy Process; Mc. GrawYHill International: New York, NY, USA, 1980.

9. Stearns, T.M.; Carter, N.M.; Reynolds, P.D.; Williams, M.L. New firm survival: Industry, strategy, and location. J. Bus. Ventur. 1995, 10, 23-42. [CrossRef]

10. Gémar, G.; Moniche, L.; Morales, A.J. Survival analysis of the Spanish hotel industry. Tour. Manag. 2016, 54, 428-438. [CrossRef]

11. Gémar, G.; Soler, I.P.; Guzmán-Parra, V.F. Predicting bankruptcy in resort. Int. J. Contemp. Hosp. Manag. 2019, 31, 1546-1566. [CrossRef] 
12. Belberdos, R.; Du, H.S.; Slangen, A. When do firms choose global cities as foreign investment locations within countries? The roles of contextual distance, knowledge intensity, and target-country experience. J. World Bus. 2020, 55, 101022.

13. Flores, R.G.; Aguilera, R.V. Globalization and location choice: An analysis of US multinational firms in 1980 and 2000. J. Int. Bus. Stud. 2007, 38, 1187-1210. [CrossRef]

14. Ramasamy, B.; Yeung, M.; Laforet, S. China's outward foreign direct investment: Location choice and firm ownership. J. World Bus. 2012, 47, 17-25. [CrossRef]

15. Mataloni, R.J. The structure of location choice for new US manufacturing investments in Asia-Pacific. J. World Bus. 2011, 46, 154-165. [CrossRef]

16. Goerzen, A.; Asmussen, C.G.; Nielsen, B.B. Global cities and multinational enterprise location strategy. J. Int. Bus. Stud. 2013, 44, 427-450. [CrossRef]

17. Friedmann, J. The World City Hypothesis. In World Cities in a World System; Cambridge University Press: Cambridge, UK, 1995; pp. 317-331.

18. Sassen, S. The Global City. In A Companion to the Anthropology of Politics; Blackwell Publishing Ltd.: Oxford, UK, 2008; pp. 168-178

19. Blevins, D.P.; Moschieri, C.; Pinkham, B.C.; Ragozzino, R. Institutional changes within the European Union: How global cities and regional integration affect MNE entry decisions. J. World Bus. 2016, 51, 319-330. [CrossRef]

20. Audretsch, B. Agglomeration and the location of innovative activity. Oxf. Rev. Econ. Policy 1998, 14, 18-29. [CrossRef]

21. Camagni, R. Innovation Networks: Spatial Perspectives; Belhaven Press: London, UK, 1991.

22. Nijkamp, P. XXQ factors for sustainable urban development: A systems economics view. Rom. J. Reg. Sci. 2008, 2, 1-34.

23. Kourtit, K.; Macharis, C.; Nijkamp, P. A multi-actor multi-criteria analysis of the performance of global cities. Appl. Geogr. 2014, 49, 24-36. [CrossRef]

24. Bartik, T.J. The Effects of Environmental Regulation on Business Location in the United States. Growth Chang. 1988, 19, 22-44. [CrossRef]

25. Lopes, A.P.F.; Muñoz, M.M.; Alarcón-Urbistondo, P. Regional tourism competitiveness using the PROMETHEE approach Ana. Ann. Tour. Res. J. 2018, 73, 1-13. [CrossRef]

26. Ostovare, M.; Shahraki, M.R. Evaluation of hotel websites using the multicriteria analysis of PROMETHEE and GAIA: Evidence from the five-star hotels of Mashhad. Tour. Manag. Perspect. 2019, 30, 107-116. [CrossRef]

27. Makan, A.; Fadili, A. Sustainability assessment of large-scale composting technologies using PROMETHEE method. J. Clean. Prod. 2020, 261, 121244. [CrossRef]

28. Brans, J.P.; De Smet, Y. PROMETHEE methods. Int. Ser. Oper. Res. Manag. Sci. 2016, 233, 187-219. [CrossRef]

29. Macharis, C.; Springael, J.; de Brucker, K.; Verbeke, A. PROMETHEE and AHP: The design of operational synergies in multicriteria analysis-Strengthening PROMETHEE with ideas of AHP. Eur. J. Oper. Res. 2004, 153, 307-317. [CrossRef]

30. World Health Organization. Healthy Cities: Good Health Is Good Politics: Toolkit for Local Governments to Support Healthy Urban Development; World Health Organization: Manila, Philippines, 2015.

31. Barber, R.M.; Fullman, N.; Sorensen, R.J.D.; Bollyky, T.; McKee, M.; Nolte, E.; Abajobir, A.A.; Abate, K.H.; Abbafati, C.; Abbas, K.M. Healthcare Access and Quality Index based on mortality from causes amenable to personal health care in 195 countries and territories, 1990-2015: A novel analysis from the Global Burden of Disease Study 2015. Lancet 2017, 390, 231-266. [CrossRef]

32. Rosenthal, S.S.; Strange, W.C. The attenuation of human capital spillovers. J. Urban Econ. 2008, 64, 373-389. [CrossRef]

33. OECD. PISA 2018 Results (Volume I): What Students Know and Can Do; OECD Publishing: Paris, France, 2019.

34. World Bank. Doing Business 2020; World Bank Publications: Washington, DC, USA, 2020.

35. UN General Assembly Transforming Our World: The 2030 Agenda for Sustainable Development. In A New Era in Global Health; Springer Publishing Company: New York, NY, USA, 2018.

36. Perales, J.A.S. De los Objetivos del Milenio al desarrollo sostenible: Naciones Unidas y las metas globales post-2015. Anu. Ceipaz 2014, 7, 49-84.

37. European Institute for Gender Equality. Gender Equality Index; European Institute for Gender Equality: Vilnius, Lithuania, 2019.

38. World Economic Forum Global Gender Gap Report 2020. Available online: https:/ / reports.weforum.org/global-gender-gapreport-2020/the-global-gender-gap-index-2020/results-and-analysis/ (accessed on 15 October 2021).

39. United Nations Development Programme. Human Development Report 2020. The Next Frontier. Human Development and the Anthropocene; United Nations Development Programme: New York, NY, USA, 2020; ISBN 978-92-1-126442-5.

40. Thees, H.; Zacher, D.; Eckert, C. Work, life and leisure in an urban ecosystem-Co-creating Munich as an Entrepreneurial Destination. J. Hosp. Tour. Manag. 2020, 44, 171-183. [CrossRef]

41. ICCA International Congress and Convention Association. Country and City Rankings. Available online: http://www.iccaworld. $\mathrm{com} /$ (accessed on 15 October 2021).

42. Transparency International the Global Coalition against Corruption, Corruption Perceptions Index. 2020. Available online: https:/ / www.transparency.org/en/cpi/2019/index/nzl (accessed on 15 October 2021).

43. World Health Organization. Global Status Report on Road Safety; World Health Organization: Geneva, Switzerland, 2015.

44. Amelung, B.; Nicolls, S.; Viner, D. Implications of Global Climate Change for Tourism Flows and Seasonality. J. Travel Res. 2007, 45, 285-296. [CrossRef]

45. Soler, I.P.; Gémar, G.; Correia, M.B. The climate index-length of stay nexus. J. Sustain. Tour. 2020, 28, 1272-1289. [CrossRef] 
46. Tarachucky, L.; Sabatini-Marques, J.; Yigitcanlar, T.; Baldessar, M.J.; Pancholi, S. Mapping hybrid cities through location-based technologies: A systematic review of the literature. Cities 2021, 116, 103296. [CrossRef]

47. Dutta, S.; Reynoso, R.E.; Lanvin, B.; Wunsh-Vicent, S.; León, L.R.; Garansvili, A.; Bayona, P. Global Innovation Index 2020. Available online: https:/ / www.globalinnovationindex.org/gii-2016-report\# (accessed on 15 October 2021).

48. Bollen, K.A. Structural Equations with Latent Variables; John Wiley and Sons: New York, NY, USA, 1989.

49. Hair, J.F.; Anderson, R.E.; Tatham, R.L.; Black, W.C. Análisis Multivariante, 5th ed.; Prentice Hall: Hoboken, NJ, USA, 1999.

50. Cronbach, L.J. Coefficient alpha and the internal structure of tests. Psychometrika 1951, 163, 297-334. [CrossRef]

51. Pérez, C. Técnicas Estadísticas con SPSS, 1st ed.; Prentice Hall: Madrid, Spain, 2001.

52. Soler, I.P.; Gemar, G. A measure of tourist experience quality: The case of inland tourism in Malaga. Total Qual. Manag. Bus. Excell. 2019, 30, 1466-1479. [CrossRef]

53. Gemar, G.; Soler, I.P.; Melendez, L. Analysis of the intent to purchase travel on the web. Tour. Manag. Stud. 2019, 15, 23-33. [CrossRef]

54. Brans, J.P. L'ingénierie de la Décision: L'élaboration D'instruments D'aide a la Décision; Presses de l'Université Laval: Laval, QC, Canada, 1982.

55. Gervásio, H.; Simões da Silva, L. A probabilistic decision-making approach for the sustainable assessment of infrastructures. Expert Syst. Appl. 2012, 39, 7121-7131. [CrossRef]

56. Brans, J.P.; Mareschal, B. The PROMCALC \& GAIA decision. Decis. Support Syst. 1994, 12, 297-310. 